Удк 343.35

DOI https://doi.org/10.32837/apdp.v0i90.3214

О. К. Марін

\title{
РОДОВИЙ ОБ'СКТ КРИМІНАЛЬНИХ ПРАВОПОРУШЕНЬ У СФЕРІ СЛУЖБОВОЇ ДІЯЛЬНОСТІ ТА ПРОФЕСІЙНӦ̈ ДІЯЛЬНОСТІ, ПОВ’ЯЗАНОЇ З НАДАННЯМ ПУБЛІЧНИХ ПОСЛУГ
}

Постановка проблеми. Криза протидії кримінальним правопорушенням у сфері службової діяльності та професійної діяльності, пов'язаної із наданням публічних послуг, корупційній злочинності, зокрема, ставить перед кримінально-правовою доктриною питання про те, чи у належному стані перебуває науково-теоретичне осмислення фундаментальних проблем кримінально-правового регулювання відповідних суспільних відносин. Видається, що адекватне розуміння родового об'єкта будь-яких кримінальних правопорушень здатне забезпечити виконання цим кримінально-правовим поняттям не лише системоутворюючої функції, а й визначальної ролі для криміналізації суспільно небезпечних посягань у аспекті реалізації принципу ultima ratio. Сучасне розуміння об'єкта кримінального правопорушення, яке переважає у роботах з кримінального права і є загальноприйнятим, як засвідчує практика і законотворення і протидії кримінальним правопорушенням у сфері службової діяльності та професійної діяльності, пов'язаної із наданням публічних послуг, такі функції виконує недостатньо добре. Поява, наприклад, у Розділі VXII Особливої частини КК України статей $364^{2}$ «Здійснення народним депутатом України на пленарному засіданні Верховної Ради України голосування замість іншого народного депутата України» та $365^{3}$ «Бездіяльність працівника правоохоронного органу щодо незаконної діяльності з організації або проведення азартних ігор, лотерей» засвідчує одне з двох: або законодавець нехтує значенням родового об'єкта кримінальних правопорушень для формування системи Особливої частини КК України, або ж такий родовий об'єкт, у зв'язку з розвитком суспільства, потребує перегляду.

Стан дослідження. Проблема родового об’єкта кримінальних правопорушень у сфері службової діяльності та професійної діяльності, пов’язаної з наданням публічних послуг, не належить до питань, яким у науці кримінального права приділено замало уваги. Практично у кожній дисертації, яка присвячується якомусь складу правопорушення або їх групі, питання родового об'єкта є предметом розгляду. Не оминають цього питання і вчені у наукових статтях та навчальній літературі. Більше того, ці дослідження містять й узагальнення підходів до визначення цього поняття. Найбільш повно та лаконічно, видається, це зробив Д.Г. Михайленко, відзначивши, що під ним розуміли чи розуміють: 1) службовий борг (обов'язок) (О.О. Жижиленко, С.В. Познишев); 2) службову діяльність посадової особи й порушення правильного здійснення нею своїх службових функцій (А.Р. Гюнтер); 3) сам державний апарат (А.А. Піонтковський); 4) державну дисципліну (А.Н. Трайнін, 1938); 5) правильну роботу державного апарату (вперше запропонував А.Н. Трайнін в 1939 р., змінивши свою думку) (Ш.Г. Папіашвілі,

(C) 0. К. Марін, 2021 
О.Я. Свєтлов, А.К. Квіцинія, В.О. Навроцький); 6) інтереси державного управління (Б.С. Утєвський); 7) якість державного апарату (О.Б. Сахаров); 8) інтереси публічної служби (Б.В. Волженкін, А.В. Шнітенков); 9) правомірну діяльність державних та інших органів, їх авторитет (Д.І. Крупко); 10) встановлений законом порядок здійснення посадовими та службовими особами своїх повноважень (П.П. Андрушко); 11) суспільні відносини соціального управління (К.П. Задоя) тощо. Сам автор розуміє під родовим об'єктом відповідних посягань встановлений законом порядок здійснення службовими особами своїх повноважень [1, с. 524]. У спеціальній літературі з приводу родового об'єкта аналізованих кримінальних правопорушень після масштабної реформи 2011 та наступних років з'явилися позиції з приводу того, що зміни, які відбулися у кримінальному законодавстві у квітні 2011 року, призвели до розширення родового об'єкта розглядуваних посягань. Фактично цей об'єкт об'єднує у собі два тісно пов'язаних між собою, але не тотожних видових об'єкта, на які посягають, відповідно, кримінальні правопорушення у сфері службової діяльності та відповідні правопорушення у сфері професійної діяльності, пов'язаної з наданням публічних послуг. О.М. Грудзур у межах родового об’єкта кримінальних правопорушень у сфері службової діяльності та діяльності, пов'язаної із наданням публічних послуг, виділяє два видових об'єкти: 1) суспільні відносини, що забезпечують нормальну діяльність державного та громадського апарату, а також апарату управління підприємств, установ, організацій незалежно від форм власності; 2) суспільні відносини, що забезпечують нормальну діяльність, пов'язану з наданням публічних функцій [2, с. 394]. B.I. Тютюгін та Ю.В. Годецький відзначають, що у розділі XVII Особливої частини КК України встановлена відповідальність за злочини, родовим об'єктом яких є суспільні відносини, що забезпечують нормальну, тобто таку, зміст, характер, межі та порядок здійснення якої визначені законодавством, діяльність державного апарату, апарату управління органів місцевого самоврядування, громадських об’єднань, інших юридичних осіб як публічного, так і приватного права, а також суспільні відносини, що забезпечують здійснення регламентованої законодавством професійної діяльності, пов'язаної із наданням публічних послуг [3, с. 273]. Таким чином, на поверхні й тексту КК України, й відповідних наукових напрацювань лежить висновок про те, що оскільки назва Розділу Особливої частини КК України містить два «види діяльності», у сфері яких можуть бути вчинені відповідні правопорушення, то й родовий об'єкт аналізованих посягань «роздвоюється» на видові: 1) сфера службової діяльності; 2) сфера професійної діяльності, пов’язаної з наданням публічних послуг.

Метою статті є спроба обгрунтування гіпотези щодо потреби розгляду родового об’єкта кримінальних правопорушень у сфері службової діяльності та професійної діяльності, пов'язаної з наданням публічних послуг за допомогою філософських категорій «суще» та «належне».

Виклад основного матеріалу. У кримінально-правовій доктрині України об’єктом кримінального правопорушення традиційно розуміють ті суспільні відносини, які поставлені під охорону кримінальним законом. Стверджується, зокрема, що «на цьому етапі розвитку доктрини кримінального права концепція об'єкта зло- 
чину як суспільних відносин виглядає найбільш переконливою та універсальною» [4, с. 45]. Такий підхід знаходить підтримку й у сучасних дослідженнях, присвячених безпосередньо аналізованій групі правопорушень. Так, Н.В. Акулова відзначила, що «родовим об'єктом цих злочинів є суспільні відносини, що забезпечують встановлену відповідними нормативним актами службову діяльність в органах державної влади, місцевого самоврядування, а також в юридичних особах публічного та приватного права» [5, с. 116]. Р.М. Гора стверджує, що «родовим об’єктом ... є сукупність однорідних суспільних відносин, які забезпечують нормальну службову діяльність службової особи органів державної влади, органів місцевого самоврядування, об’єднань громадян, підприємств, установ та організацій незалежно від форми власності, а також професійну діяльність, пов'язану з наданням публічних послуг, і які охороняються єдиним комплексом норм, передбачених розділом XVII Особливої частини КК України» [6, с. 43]. «Родовим об'єктом складів злочинів, які полягають у прийнятті пропозиції, обіцянки або одержанні неправомірної вигоди, є суспільні відносини, що визначають і регулюють зміст правильної (нормальної), тобто такої, яка відповідає встановленим вимогам законодавства, діяльності органів державної влади, органів місцевого самоврядування, юридичних осіб приватного та публічного права, підприємств, установ та організацій, а також осіб, які надають публічні послуги», запевняє М.Б. Желік [7, с. 69]. Нарешті, В.В. Андрієшин вказує читачеві на те, що «основним об’єктом системи відповідних злочинів є «сфера службової діяльності»- суспільні відносини, які виникають, функціонують та припиняються у зв'язку з регламентованою нормативно-правовими та локальними актами діяльністю щодо реалізації службовими особами наданих їм повноважень» [8, с. 110]. Цитування авторів можна продовжувати й надалі, i, враховуючи величезну кількість публікацій, в яких зачіпається проблема родового об’єкта кримінальних правопорушень у сфері службової діяльності та професійної діяльності, пов'язаної з наданням публічних послуг, вийти за всі розумні межі. Суть проблеми, думається, полягає у такому.

Аналізуючи наявне у кримінально-правовій доктрині розуміння предмету цієї статті, варто виокремити два моменти. Перше - яка субстанція є власне об’єктом i, друге - що є змістом цієї субстанції.

Відповідаючи на перше запитання, прибічники концепції «об’єкт правопорушення - суспільні відносини», окрім, звичайно, іншого, вказують, що «відносини, які виступають об'єктом злочину, первинні стосовно не тільки стосовно кримінального закону, а й самого злочину. Злочин завжди посягає на об'єктивно існуючий об'єкт, на певну реальність. Не можна посягати на те і завдавати шкоду тому, чого ще немає в об’єктивній дійсності» [4, с. 50]. Це твердження складно піддається критиці, однак, якщо поглянути на об'єкт кримінального правопорушення дещо з іншої точки зору - його розуміння може змінитися.

Так, реальність, буття, яке відображається у кримінально-правових дослідженнях із використанням категорії «суспільні відносини», належить до філософської категорії «суще». Філософи права наділяють цю категорію відповідним змістом, як, наприклад, у такому випадку: «Суще, це наявне буття, виражене у системі норм позитивного права: в діючих нормативно-правових актах, правових звичаях, 
судових рішеннях" [9, с. 12]. Щодо розв'язуваної проблеми, видається, світоглядний підхід такий - ми маємо відповідні суспільні відносини, які існують реально, зі своїми суб'єктами, предметами та зв'язками, та на думку законодавця потребують кримінально-правової охорони. У зв'язку із цим законодавець формулює та об’єктивує у кримінальному законі кримінально-правові заборони, які спрямовані на охорону таких суспільних відносин і містять склади конкретних кримінальних правопорушень. Формується правовий зміст категорії «суще» .

Що це так з цієї концепцією, чому вона може бути переглянута i у якому напрямі? Видається, що наведена цільова установка законодавця на відображення у нормативних приписах реально існуючих суспільних відносин у нашій галузі права містить небезпеку неефективності та відставання від наддинамічних суспільних відносин, що фактично й спостерігається. Прикладів цьому є не те, що багато, а - вся сучасна історія реформування кримінального законодавства щодо протидії кримінальним правопорушенням у сфері службової діяльності та професійної діяльності, пов'язаної із наданням публічних послуг: ст. 364 змінена 9 разів; введена до КК у 2011 році ст. $364^{1}$ - змінена за 10 років 7 разів; $368^{2}$, введена до КК у 2011 році змінювалася 5 разів і в результаті визнана Конституційним Судом України такою, що не відповідає Конституції України і т.д. Стосовно реалій протидії цій групі кримінальних правопорушень коментарі зайві.

Яким може бути інший підхід, інша точка зору або позиція? Є підстави вважати, що виправданим буде використання філософської категорії «належне», якій філософи права також надають специфічного змісту: «Належне - це ідеальні основи, конструкції, що виражають ідеальний стан правової системи. Пошуки належного - це пошуки універсальних понять, їх основною метою є керівний ідеал, а не конкретний припис» [9, с. 12]. Щодо розв'язуваної проблеми, видається, світоглядний підхід може бути такий: ми визначаємо ідеальний стан того, що прагне суспільство із урахуванням базових принципів його функціонування, виокремлюємо ті цінності, блага, вартості, як завгодно, які ми бажаємо забезпечити існуванням кримінально-правової заборони, що містить склад конкретного кримінального правопорушення, і на підставі цього формулюємо та об’єктивуємо відповідний правовий припис. Таким чином ми змінюємо цілеустановку законодавця з відображення «сущого» на формування «належного» .

Яка ж з концепцій об’єкта кримінальних правопорушень найближче до викладеного вищепідходу? Нам видається, що концепція «об’єкт правопорушення - правове благо». Поняття правових благ та їх захист розглядається як продукт раннього лібералізму XIX століття у німецькій доктрині кримінального права. Коротко і виразно визначає цілі вчення про правове благо В. Хассемер. На його думку, це вчення:

1) приводить у відповідність завдання кримінального права з кримінальною політикою;

2) є природженим ворогом розуміння злочину як чистого порушення обов'язку, відсилаючи законодавця до емпіричних субстратів та залишаючи за ним лише свободу вибору обсягу та техніки захисту в конституційному просторі;

3) збагачує теорію кримінального права відмінностями, які допоможуть краще пояснити систему і задачі кримінального права; 
3) здатне зробити рішення законодавця про обсяг та техніку правового захисту прозоріше, доступніше для огляду [10, с. 307].

Правове благо, за визначенням У. Вебера, це одухотворена ідеальна, тобто відображена у свідомості, цінність. При цьому панівна наукова позиція стверджує, що захист правового блага завжди лежить в основі заборони кримінально караного діяння [10, с. 307]. Фактично те, про що відзначалося у цій статті вище. Більше того, сприйняття концепції правового блага як об’єкта кримінального правопорушення зможе дати відповідь не тільки на питання, що має стати під охорону кримінального права, а й чому. Суть цієї концепції зводиться до того, що «правовим благом» називають умови рівноправного розвитку особистості, що забезпечуються законом. Критерії оцінки поведінки, які виводяться з такого підходу, зводяться до лаконічної формули: крилінально-правові норми поведінки повинні служити захисту правових благ. Правові блага - це такі, що підлягають захисту, інтереси як окремої особистості, так і всього суспільства... Як індивідуальні, так і суспільні правові блага в результаті покликані створювати можливості для розвитку індивіда. Різниця між ними полягає лише в тому, що посягання на індивідуальне правове благо безпосередньо пригнічує можливості розвитку конкретної людини, тоді як посягання на універсальне правове благо опосередковано пригнічує можливості розвитку всіх членів суспільства [11, с. 48].

Таким чином, у цій роботі під субстанцією, яка підлягає кримінально-правовій охороні, пропонується розуміти «правове благо». Однак це лише перша половина проблеми. Наступним кроком для її вирішення має стати визначення змісту цієї субстанції, правового блага, а конкретніше: відповідь на запитання, а що ж складає цю відображену у свідомості цінність, реалізація якої наблизить нас до досягнення категорії «належне»? Сучасний стан розуміння змісту родового об'єкта кримінальних правопорушень у сфері службової діяльності та професійної діяльності, пов'язаної із наданням публічних послуг, наведений нами у вступній частині статті в узагальненні, проведеному Д.Г. Михайленком. При цьому очевидно, що об'єктом посягання не може бути апарат управління, обов'язок, службова діяльність, управління і тому подібні явища, оскільки вони не є тією цінністю чи благом, якого прагне суспільство. Видається, що таким благом є якісна характеристика відповідного явища, яка і перетворює його на бажаний ідеал. Не можна стверджувати, що у сучасній Україні відсутній апарат управління чи службова діяльність або професійна діяльність, пов'язана із наданням публічних послуг. Ці явища очевидно існують, питання у тому, як вони характеризуються, якої вони якості. У спеціальній літературі для позначення цієї ключової, як видається, ознаки родового об'єкта кримінальних правопорушень, передбачених Розділом VXII Особливої частини КК, застосовуються близькі за змістом терміни «встановлений законом порядок», «правильна, правильний», «нормальна, нормальний». Нам імпонує термін «нормальний, -а», який дає можливість досить об'ємно охарактеризувати аналізовану субстанцію. Нормальний в українській мові означає - який не має відхилень від норми; який відповідає загальноприйнятим нормам, установленим вимогам і т. ін.; звичайний [12]. Цей прикметник у визначенні родового об’єкта аналізованих кримінальних правопорушень використовувався і раніше [13, с. 7], використо- 
вується і зараз [2, с. 394]. Необхідним видається визначити його зміст. Перше, що приходить на думку у зв'язку із використанням терміну «нормальний, -а» у сфері права, - це такий, які здійснюється відповідно до норм права, унормований. Щодо тієї діяльності, яка зазначається у назві Розділу VXII Особливої частини КК України: службової та професійної із надання публічних послуг, жодних застережень не виникає. Вона унормована, її здійснення відбувається відповідно із нормами права. Однак це, напевно не є повним змістом, значенням словосполучення «нормальна службова діяльність та діяльність, пов'язана з наданням публічних послуг». Наступною складовою частиною такої «нормальності» є відсутність відхилень від норми - ідеальної моделі поведінки спеціального суб'єкта, який наділений можливостями у зв'язку власне зі своїм спеціальним статусом. Іншими словами, ми повинні визначити, яка службова діяльність та професійна діяльність із надання публічних послуг є нормальною - такою, якою ї̈ хоче бачити суспільство. Найпростішим, однак від того не найгіршим способом, є звернення до об'єктивованих назовні очікуваннях суспільства від осіб, які виступають спеціальними суб'єктами у розглядуваних кримінальних правопорушеннях. Такі «суспільні очікування» відображені, зокрема, у Законах України, якими урегульована поведінка визначених спеціальних суб'єктів. Таких нормативно-правових актів, насправді, $€$ багато і звернення до всіх них не має у статті змісту. Тут нам важливий принцип, відповідно до якого можна виявити відповідні риси, властивості, ознаки цього аспекту «нормальності» очікуваної поведінки спеціальних суб’єктів. Наведемо декілька прикладів, які покажуть, як це працює.

Так, преамбула до Закону України «Про державну службу» проголошує, що цей Закон визначає принципи, правові та організаційні засади забезпечення публічної, професійної, політично неупередженої, ефективної, орієнтованої на громадян державної служби, яка функціонує в інтересах держави і суспільства, а також порядок реалізації громадянами України права рівного доступу до державної служби, що базується на їхніх особистих якостях та досягненнях. Ч. 2 ст. 1 цього ж Закону визначає державного службовця як громадянина України, який займає посаду державної служби в органі державної влади, іншому державному органі, його апараті (секретаріаті) (далі - державний орган), одержує заробітну плату за рахунок коштів державного бюджету та здійснює встановлені для цієї посади повноваження, безпосередньо пов'язані з виконанням завдань і функцій такого державного органу, а також дотримується принципів державної служби [14]. У цих нормативних положеннях стосовно такої особи, як «державний службовець», встановлено вимоги щодо діяльності в інтересах держави і суспільства, одержання заробітної плати з бюджету, виконання встановлених для посади повноважень, дотримання принципів державної служби, серед яких є принципи професіоналізму та ефективності тощо. Подібні положення можна віднайти і у іншому регулятивному законодавстві, починаючи від Конституції України і до положень про міністерства чи відомства, які мають підзаконний характер. Справедливим буде також твердження, що вимоги до «очікуваних" властивостей стосовно інших суб'єктів кримінальних правопорушень у сфері службової діяльності та діяльності із наданням публічних послуг (службових осіб юридичних осіб приватного права, осіб, які на професійних 
засадах надають публічні послуги тощо) можна вивести з аналізу законодавства України та локальних актів юридичних осіб.

Висновки та перспективи дослідження. Підсумовуючи викладене, вважаємо за необхідне зосередити увагу наукової спільноти на тому, що родовим об'єктом кримінальних правопорушень у сфері службової діяльності та професійної діяльності, пов'язаної із наданням публічних послуг, варто вважати таку субстанцію, як «правове благо» у розумінні відображеної у свідомості, ідеальної цінності, «належного», що забезпечує можливості для рівноправного розвитку індивіда. Змістом «правового блага» при цьому є нормальна службова діяльність та професійна діяльність із надання публічних послуг. «Нормальність» такої діяльності складається із двох аспектів: унормованості та властивості, яка, як оціночна категорія, містить у собі такі складові частини:

1) службова діяльність та професійна діяльність із надання публічних послуг здійснюється виключно на виконання функцій юридичної особи, органу державної влади чи місцевого самоврядування або ж завдань професійної діяльності, пов’язаної із наданням публічних послуг та в їх інтересах, в інтересах того, хто доручив, наділив спеціального суб'єкта додатковими можливостями (складова частина убезпечення від зловживань);

2) службова діяльність та професійна діяльність із надання публічних послуг здійснюється виключно в межах спеціальної правоздатності: службова особа або особа, яка професійно надає публічні послуги, може діяти лише у межах та у спосіб, передбачений його спеціальним статусом (складова частина убезпечення від перевищень);

3) службова діяльність та професійна діяльність із надання публічних послуг здійснюється виключно за встановлену законом, положенням, наказом або договором плату, сума якої визначається характером виконуваної роботи, є адекватною такій роботі та офіційною, такою, що підлягає облікові та оподаткуванню (складова частина убезпечення від підкупу );

4) службова діяльність та професійна діяльність із надання публічних послуг здійснюється відповідними особами сумлінно та належно (складова частина убезпечення від недбалості).

Іншими словами, нормальна службова діяльність та професійна діяльність із надання публічних послуг - це сумлінна, належна діяльність, яка провадиться відповідно до визначених функцій та завдань у межах компетенцій та оплачується відповідно до встановлених тарифів, ставок, договору правомірно в адекватному розмірі.

\section{Jimepamypa}

1. Михайленко Д.Г. Поняття та структура об'єкта злочинів у сфері службової діяльності. Актуальні проблеми держави і права. 2013. Вип. 67. С. 521-531.

2. Кримінальне право (Особлива частина) : підручник / За редакцією О.О. Дудорова, Є.О. Письменського. Т. 2. Луганськ : Видавництво Елтон-2, 2012. С. 394.

3. Тютюгін В.І., Гродецький Ю.В. Злочини у сфері службової діяльності та професійної діяльності, пов'язаної з наданням публічних послуг: загальна характеристика. Вісник Асоиіації кримінального права України. 2015. № 1(4). С. 272-295.

4. Тацій В.Я. Об'єкт і предмет злочину в кримінальному праві : монографія. Харків : Право, 2016. $256 \mathrm{c}$. 
5. Акулова Н.В. Загальна характеристика злочинів, передбачених розділом XVII Особливої частини Кримінального кодексу України. Науковий вісник Міжнародного гуманітарного університету. Сер.: Юриспрудениія. 2015. № 8. Том 2. С. 115-117.

6. Гора Р.М. Кримінальна відповідальність за зловживання повноваженнями службовою особою юридичної особи приватного права незалежно від організаційно-правової форми : дис. ... к. ю. н. Харків : Науково-дослідний інститут вивчення проблем злочинності імені академіка В.В. Сташиса НАН України, 2019. 208 с.

7. Желік М.Б. Прийняття пропозиції, обіцянки або одержання неправомірної вигоди: кримінально-правова характеристика : дис. к. ю. н. Львів : Національний університет «Львівська політехніка», 2018. 258 c.

8. Андрієшин В.В. Структуризація об’єктів злочинів, які вчиняються службовими особами. Науковий вісник Міжнародного гуманітарного університету. Серія: Юриспруденція. 2019. № 42. Том 2. С. $110-114$.

9. Гураленко Н. Деякі аспекти проблематики антиномій права. Юридична Україна. 2012. № 12. C. $9-13$.

10. Уголовное право ФРГ как социальный институт. А.Э. Жалинский. Избранные труды. Тол. 3. Уголовная политология. Сравнительное и международное право. Москва : Высшая школа экономики, $2015.454 \mathrm{c}$.

11. Фристер Гельмут Уголовное право Германии. Общая часть : пер. с нем. 5 изд. Москва : Инфотропик Медиа, 2013. 712 с.

12. Академічний тлумачний словник української мови. URL : http://sum.in.ua/s/normaljnyj.

13. Квициния А.К. Должностные преступления. Москва : Российское право, 1992. 224 с.

14. Про державну службу : Закону України від 10.12.2015 року. URL : https://zakon.rada.gov.ua/ laws/show/889-19/conv\#Text.

\section{Анотація}

Марін О. К. Родовий об’єкт кримінальних правопорушень у сфері службової діяльності та професійної діяльності, пов'язаної з наданням публічних послуг. - Стаття.

У статті зазначається, що родовим об'єктом кримінальних правопорушень у сфері службової діяльності та професійної діяльності, пов'язаної із наданням публічних послуг, варто вважати таку субстанцію, як «правове благо» в розумінні відображеної у свідомості ідеальної цінності, «належного», що забезпечує можливості для рівноправного розвитку індивіда. Змістом «правового блага» при цьому є нормальна службова діяльність та професійна діяльність із надання публічних послуг. «Нормальність» такої діяльності складається із двох аспектів: унормованості та властивості, яка, як оціночна категорія, містить у собі такі складові частини:

1) службова діяльність та професійна діяльність із надання публічних послуг здійснюється виключно на виконання функцій юридичної особи, органу державної влади чи місцевого самоврядування або ж завдань професійної діяльності, пов'язаної із наданням публічних послуг та в їх інтересах, в інтересах того, хто доручив, наділив спеціального суб'єкта додатковими можливостями (складова частина убезпечення від зловживань);

2) службова діяльність та професійна діяльність із надання публічних послуг здійснюється виключно в межах спеціальної правоздатності - службова особа або особа, яка професійно надає публічні послуги, може діяти лише в межах та у спосіб, передбачений його спеціальним статусом (складова частина убезпечення від перевищень);

3) службова діяльність та професійна діяльність із надання публічних послуг здійснюється виключно за встановлену законом, положенням, наказом або договором плату, сума якої визначається характером виконуваної роботи, є адекватною такій роботі та офіційною, такою, що підлягає облікові та оподаткуванню (складова частина убезпечення від підкупу);

4) службова діяльність та професійна діяльність із надання публічних послуг здійснюється відповідними особами сумлінно та належно (складова частина убезпечення від недбалості).

Ключові слова: правові блага, складова частина убезпечення від зловживань, складова частина убезпечення від перевищень, складова частина убезпечення від підкупу, складова частина убезпечення від недбалості. 


\section{Summary}

Marin $O . K$. Group object of criminal offenses in the field of official activities and professional activities related to the provision of public services. - Article.

The article states that the group object of criminal offenses in the field of official activities and professional activities related to the provision of public services should be considered as such a substance as legal good in the sense of reflected in the mind, ideal value, the proper one, that provides opportunities for equal development of the individual. The essence of the legal good is the normal official activities and professional activities related to the provision of public services. The normality of such activities consists of two aspects: the normalization and the quality, which, as an evaluation category, contains the following components:

1) official activities and professional activities related to the provision of public services are carried out exclusively for the performance of functions of the legal entity, state body or local self-government body or tasks of the professional activities related to the provision of public services and in their interests, in the interests of the commissioner, the one who endowed the special subject with additional opportunities (the component of protection against abuse);

2) official activities and professional activities related to the provision of public services are carried out exclusively within the limits of special legal capacity - an official or a person who professionally provides public services may act only within the limits and in the manner provided by his/her special status (the component of protection against excess);

3) official activities and professional activities related to the provision of public services are carried out exclusively for a fee established by the law, regulation, order or contract, the amount of which is determined by the nature of the work performed, is adequate to such work and official, that is subject to accounting and taxation (the component of protection against bribery);

4) official activities and professional activities related to the provision of public services are carried out by the relevant persons conscientiously and properly (the component of protection against negligence).

Key words: legal good, the component of protection against abuse, the component of protection against excess, the component of protection against bribery, the component of protection against negligence. 